\title{
Sulfated exopolysaccharide production and nutrient removal by the marine diatom Phaeodactylum tricornutum growing on palm oil mill effluent
}

\author{
Muhamad Maulana Azimatun Nur ${ }^{1,2}$ (D) Manasveni Kilnagar Swaminathan ${ }^{2}$ - P. Boelen ${ }^{2}$ - A. G. J. Buma ${ }^{2}$
}

Received: 5 July 2018 / Revised and accepted: 4 March 2019 / Published online: 16 March 2019

(C) The Author(s) 2019

\begin{abstract}
Palm oil mill effluent (POME) is the major source of environmental hazard in palm oil industry. Yet, due to its high nutrient content, POME may offer opportunities for the growth of algae as a source of value-added compounds such as sulfated extracellular polysaccharide (sEPS) while simultaneously removing valuable nutrients such as phosphate. The aim of this paper was to evaluate growth, total sEPS production, and nutrient removal by the diatom Phaeodactylum tricornutum grown on POME under a range of experimental conditions (temperature, salinity, supplementation of extra nutrients). Phaeodactylum tricornutum was found to grow well on a range of POME concentrations, with 30\% POME as optimum concentration. Nitrate and urea addition enhanced both growth rate and final biomass, whereas phosphate significantly stimulated growth only at low temperature. Box-Behnken response surface methodology revealed that interactions between temperature and salinity, and between temperature and urea influenced sEPS production. The highest total sEPS $\left(140 \mathrm{mg} \mathrm{L}^{-1}\right)$ concentration was recorded at $25{ }^{\circ} \mathrm{C}$, $2.6 \%$ salinity, and $100 \mathrm{mg} \mathrm{L}^{-1}$ urea addition. Our study shows that POME wastewater, supplemented with urea at relatively high temperatures, can be considered as a potential medium for $P$. tricornutum to replace commercial nutrients while producing high amounts of sEPS and removing almost $90 \%$ of phosphorous from the wastewater.
\end{abstract}

Keywords POME wastewater $\cdot$ Temperature $\cdot$ Extracellular polysaccharide $\cdot$ Phaeodactylum tricornutum $\cdot$ Box-Behnken $\cdot \mathrm{sEPS}$

\section{Introduction}

Palm oil mill effluent (POME) is agricultural wastewater generated from palm oil processing. Presently, Asian coconut palm oil (CPO) production comprises $87.8 \%$ of the total world production of 57.32 million $t$. Within this region, Indonesia is currently known as the largest CPO producer, followed by Malaysia (Faostat 2018). Direct discharge of POME into the environment causes severe pollution due to its high organic

Electronic supplementary material The online version of this article (https://doi.org/10.1007/s10811-019-01780-2) contains supplementary material, which is available to authorized users.

Muhamad Maulana Azimatun Nur

m.m.azimatun.nur@rug.nl; lanaazim@upnyk.ac.id

1 Department of Chemical Engineering, Faculty of Industrial Technology, Universitas Pembangunan Nasional "Veteran", Yogyakarta, Indonesia

2 Department of Ocean Ecosystems, Energy and Sustainability Research Institute, Faculty of Science and Engineering, University of Groningen, Groningen, The Netherlands matter content, high chemical oxygen demand (COD), biochemical oxygen demand (BOD), high nutrient levels, dark color, and strong smell (Nur et al. 2017). To date, the conventional ponding system is the most common method for treating POME (Liew et al. 2014). In Malaysia, more than $85 \%$ of palm oil mills have adopted the ponding system due to its low capital cost (Tong and Jaafar 2004). Nevertheless, the conventional ponding system has various limitations such as low nutrient removal efficiency, long retention times, and enhanced greenhouse gas emissions (Tabassum et al. 2015). The strategy to decrease adverse characteristics of POME by using microalgae while simultaneously producing value added products could be promising due to the fact that POME contains high micro- and macronutrient levels (Nur and Buma 2018). However, the nutrient removal efficiency by microalgae will also depend on cultivation conditions as well as on nutrient composition in terms of speciation and initial N/P ratio (Beuckels et al. 2015). Given the worldwide phosphorus shortage, nutrient conditions within cultivation systems should be optimal or otherwise optimized such that complete phosphate removal from the wastewater is achieved. 
Extracellular polysaccharide or exopolysaccharide (EPS) is a group of polysaccharide substances generated from secondary metabolic processes within algae, excreted under normal as well as under unfavorable conditions (De Jesus Raposo et al. 2013; Ates 2015). EPS may contain xylose, galactose, or glucose. In addition, sulfated exopolysaccharides (sEPS) are formed, which may be attached to lipids or proteins, depending on the cultivated algal species (Delattre et al. 2016). In general, the overall composition of sEPS is species specific. For example, sEPS produced by P. tricornutum contains 7.5$13.3 \%$ sulfate, and $1.4-6.3 \%$ uronic acids, while sEPS from Chlorella stigmatophora contains 7.8-9.4\% sulfate and 3.79.0 uronic acid (Guzmán et al. 2003).

Recently, the interest in utilizing EPS from microalgae has increased. Several applications have been widely implemented in agricultural fields to improve soil properties, and thereby to enhance plant growth (Painter 1993). In the pharmaceutical field, sEPS from $P$. tricornutum is promising as an anti-inflammatory, antiviral, antiparasitic, anti-tumor, and hypocholesterolemic compond (Guzmán et al. 2003; De Jesus Raposo et al. 2013; Delattre et al. 2016). However, the production of microbial sEPS at a large scale, especially from microalgae, is limited due to the high production cost (Ates 2015). Alternatively, the cultivation of microalgae on POME with the aim to produce SEPS and carbohydrates could be promising, given the relatively high nutrient content of the wastewater, thereby making commercial nutrients redundant. Furthermore, the treated sEPS containing POME might be utilized for soil improvement in the vicinity of the palm oil plants.

It has been suggested that culture conditions and nutrient composition of the medium influence the sEPS production of microalgae (Guzmán-Murillo et al. 2007; Ekelhof and Melkonian 2017). Microalgae tend to produce higher sEPS under stressed conditions such as excess irradiance and supraoptimal temperatures, as a means to prevent cell damage via the action of exopolymers (Kumar et al. 2007; Delattre et al. 2016). Other factors such as nutritional conditions and salinity were also reported to influence EPS production and composition (Abdullahi et al. 2006; Díaz Bayona and Garcés 2014). However, based on our knowledge, the influence of temperature on EPS production was not yet explored. Furthermore, the interaction between these parameters was not well reported so far. Therefore, it can be assumed that total biomass, total sEPS, and intracellular carbohydrate productivity by $P$. tricornutum cultivated on POME would be influenced by environmental conditions such as salinity, nutrient availability and temperature. The aim of this research was to study the utilization of nutrient enriched POME and the interaction of urea addition, salinity, and temperature on growth, nutrient removal, sEPS, and biomass production of $P$. tricornutum. We chose urea addition because it guarantees complete phosphorus removal (Nur et al. 2019). Furthermore, excess nutrients from the wastewater that cause eutrophication could be treated by using microalgae since it is cost-effective compared to chemical wastewater treatment (Smith et al. 1998; Delrue et al. 2016). In order to find optimal cultivation conditions, we employed response surface methodology (RSM) based from Box-Behnken design (BBD).

We chose the marine diatom $P$. tricornutum as test alga since $P$. tricornutum was shown previously to grow on POME (Nur and Buma 2018). Furthermore, sEPS composition of $P$. tricornutum, which mainly consist of glucose, mannose, and galactose, was also affected by environmental conditions such as salinity and nutrient addition (Abdullahi et al. 2006). Finally, in contrast to most diatoms, P. tricornutum has a cell wall that is rich in sulfated polysaccharides and poor in silica (Le Costaouëc et al. 2017). Therefore, P. tricornutum could be a promising candidate as a source of sEPS, when growing on POME in an optimum condition.

\section{Material and methods}

\section{Wastewater preparation}

POME was obtained from a small factory in Sumatra, Indonesia, after it had been released from an aerobic open pond lagoon. The wastewater was stored at $-19^{\circ} \mathrm{C}$ to prevent degradation over a long time period. The wastewater was thawed and filtered with GF/C glass fiber filters (Whatmann, $47 \mathrm{~mm}$ ) to remove particulate matter. Subsequently, the filtrate was sterilized at $121^{\circ} \mathrm{C}$ for $15 \mathrm{~min}$. This treated POME contained $1245 \mathrm{mg} \mathrm{L}^{-1} \mathrm{COD}$, $72.4 \mathrm{mg} \mathrm{L}^{-1}$ total dissolved nitrogen (TDN), and $7.93 \mathrm{mg} \mathrm{L}^{-1}$ total dissolved phosphorus (TDP), as determined using the assay kits LCK349 and LCK138 (Hach Lange).

\section{Experimental setup}

Precultures of $P$. tricornutum Bohlin (CCMP2558, NCMA, Maine, USA) were grown on a standard $\mathrm{f} / 2$ medium based on filtered natural oligotrophic seawater obtained from NIOZ Netherlands (adjusted to a salinity of $3.5 \%(w / v)$ with demineralized water) by the protocol of Guillard (1975) supplemented with silicate $(100 \mu \mathrm{M})$. The algae were cultivated in a $16: 8 \mathrm{~h}$ light dark cycle at a temperature of $25^{\circ} \mathrm{C}$. The cultures were illuminated with fluorescent lamps (see below) providing $300 \mu \mathrm{mol}$ photons $\mathrm{m}^{-2} \mathrm{~s}^{-1}$. The cultures were diluted with fresh Guillard medium if growth reached the stationary phase. The cultures were acclimated to the experimental conditions for at least 1 week prior to experimentation. In total, four experiments were done.

\section{Determination of the optimal POME concentration for $P$. tricornutum growth}

Six concentrations of POME $(5-100 \% v / v)$ and one control (f/2) were prepared based on appropriate dilutions in sterilized 
oligotrophic seawater. The $\mathrm{pH}$ of each concentration was adjusted to 8 by using $2 \mathrm{~N} \mathrm{NaOH}$ or $\mathrm{HCl}$, and the salinity was set to $3.5 \%(w / v)$ by using commercially available artificial sea salt (Reef Salt, Aqua Medic, Germany). All media were supplemented with silicate $(100 \mu \mathrm{M})$. Two replicates (each $75 \mathrm{~mL}$, in $100 \mathrm{~mL}$ Erlenmeyer flasks) were made for each concentration. Phaeodactylum tricornutum (2\% v/v, which equals an initial cell density of around $15 \times 10^{4}$ cells $\mathrm{mL}^{-1}$ ) was inoculated into each flask, and the cultures were incubated in a water bath at $25^{\circ} \mathrm{C}$ and a light/dark cycle of $16 \mathrm{~h}: 8 \mathrm{~h}$. The water bath was equipped with a temperature controller and a U shaped lamp that contained 12 fluorescent lamps (six Biolux and six skywhite lamps, Osram) coupled to reflectors (Doublelux) and connected to dimmers (Osram) and set as described by Van de Poll et al. (2007). The culture flask was closed with a cotton stopper and gently shaken manually every day to resuspend the cells and to provide aeration to the cells. For all experiments, a saturating light intensity (300 $\mu \mathrm{mol}$ photons $\mathrm{m}^{-2} \mathrm{~s}^{-1}$ ) was used as determined earlier (Nur et al. 2019). Due to the variable irradiance penetration in the culture flasks as a result of the different POME fractions, the light intensity was adjusted using neutral density screens. The light intensity was measured in the center of culture flask by using a spherical light sensor (Biospherical Instruments QSL2101, USA) which is small enough to be placed inside the culture flasks. Every $24 \mathrm{~h}, 1 \mathrm{~mL}$ of sample was taken from each culture flask and direct cell counting was performed using a hemocytometer under a light microscope. At least 200 cells were counted using a hand counter. The cultivation was stopped at the end of the exponential phase (4-7 days).

\section{Effects of different nutrient additions on $P$. tricornutum biomass and sEPS production when growing on 30\% POME}

Phaeodactylum tricornutum was cultured in $75 \mathrm{~mL}$ working volume in $100-\mathrm{mL}$ sterilized Erlenmeyer flasks and placed in a water bath as described above. About $2 \%(v / v)$ of $P$. tricornutum culture was used as inoculate to autoclaved and filtered medium consisting of $30 \% v / v$ POME $+70 \% v / v$ filtered natural oligotrophic seawater. Cultures growing on $30 \%$ POME alone (no nutrient additions) served as controls. Nitrogen and phosphorus were added to the media to generate different N/P molar ratios (Table 2). All media were supplemented with silicate $(100 \mu \mathrm{M})$. The experiments were carried out at 20 and $25{ }^{\circ} \mathrm{C}$, initial $\mathrm{pH}$ was adjusted to $8.0 \pm 0.2$ by using $2 \mathrm{~N} \mathrm{HCl}$ or $2 \mathrm{~N} \mathrm{NaOH}$, and salinity was adjusted to $3.5 \% w / v$ using artificial sea salt (Reef Salt, Aqua Medic, Germany). The light intensity was set to $300 \mu \mathrm{mol}$ photons $\mathrm{m}^{-2} \mathrm{~s}^{-1}$ inside the cultivation medium. Every $24 \mathrm{~h}$, a $1 \mathrm{~mL}$ of sample was taken from each culture flask and direct cell counting was performed using a hemocytometer under a light microscope. At the end of the exponential growth phase
(7-15 days cultivation), the cultures were harvested for sEPS, biomass (dry weight), and intracellular carbohydrate.

\section{Effect of salinity, temperature, and urea addition on growth rate, biomass, and sEPS production of $P$. tricornutum growing on $30 \%$ POME}

General full factorial design (GFFD) with three variables was performed to determine the factor most affecting sEPS and biomass production as well as their interactions with respect to the growth rate. A further experiment based on FFD was employed using Box-Behnken design (BBD) response surface methodology (RSM) to study the optimum value of the variables for biomass and sEPS production. The empirical form of the second order polynomial model for BBD can be described as (Eq. 1)

$y=\beta_{0}+\sum \beta_{\mathrm{i}} x_{\mathrm{i}}+\sum \beta_{\mathrm{ii}} x_{\mathrm{i}}^{2}+\sum \beta_{\mathrm{ij}} x_{\mathrm{i}} x_{\mathrm{j}}$

where $y$ is the predicted value; and $\beta_{0}, \beta_{\mathrm{i}}, \beta_{\mathrm{ii}}$, and $\beta_{\mathrm{ij}}$ are the constant, linear, quadratic, and the interaction coefficient, respectively.

The experimental design, based on two replicates, consisted of three factors, temperature $\left(20,22.5,25^{\circ} \mathrm{C}\right)$, salinity $(0.5,2.0,3.5 \% w / v)$, and urea addition $(0,50$, $\left.100 \mathrm{mg} \mathrm{L}^{-1}\right)$. The alga was cultured in $75 \mathrm{~mL}$ working volume in a $100-\mathrm{mL}$ sterilized Erlenmeyer flask and placed in the water bath equipped with $U$ shaped lamps and temperature controller as described above. About $2 \%(v / v)$ of $P$. tricornutum culture was used as inoculate to the medium consisting of $30 \% v / v$ POME $+70 \% v / v$ seawater. Salinity was adjusted by using seawater and Milli-Q water. All media were supplemented with silicate $(100 \mu \mathrm{M})$, and $\mathrm{pH}$ was adjusted to $8 \pm 0.2$ by using $2 \mathrm{~N} \mathrm{HCl}$ or $2 \mathrm{~N} \mathrm{NaOH}$ at the beginning of the cultivation. The light intensity was set to $300 \mu \mathrm{mol}$ photons $\mathrm{m}^{-2} \mathrm{~s}^{-1}$ inside the cultivation medium. About $1 \mathrm{~mL}$ of the sample was taken daily and preserved using $1 \% \mathrm{v} / \mathrm{v}$ Lugols iodine. The cell density was counted by using a hemocytometer until the cultures reached the end of the exponential phase (7 days). Then, cultures were harvested for analyses of final biomass (dry weight) and sEPS.

\section{Effect of nutrient enrichment on nutrient removal efficiency of POME}

Phaeodactylum tricornutum was cultured in 75-mL working volume in 100-mL sterilized Erlenmeyer flasks and placed in a water bath as described above. About $2 \%(v / v)$ of $P$. tricornutum culture was used as inoculate to autoclaved and filtered medium consisting of $30 \% v / v$ POME $+70 \% v / v$ filtered natural oligotrophic seawater. Cultures growing on $30 \%$ POME alone (no nutrient additions) served as control. Different nutrient enrichments were employed, $50 \mathrm{mg} \mathrm{L}^{-1}$ of 
urea (U), and $3 \mathrm{mg} \mathrm{L}^{-1}$ of phosphate (P). All media were supplemented with silicate $(100 \mu \mathrm{M})$. The experiments were carried out at $20{ }^{\circ} \mathrm{C}$, initial $\mathrm{pH}$ was adjusted to $8.0 \pm 0.2$ by using $2 \mathrm{~N} \mathrm{HCl}$ or $2 \mathrm{~N} \mathrm{NaOH}$, and salinity was adjusted to $3.5 \%(w / v)$ using artificial sea salt (Reef Salt, Aqua Medic, Germany). The light intensity was set to $300 \mu \mathrm{mol}$ photons $\mathrm{m}^{-2} \mathrm{~s}^{-1}$ inside the cultivation medium. At the beginning of cultivation and the end of the exponential growth phase (7-9 days), the culture was filtered using GF/F glassfiber filters and nutrients were analyzed in the filtrate to obtain nutrient removal efficiency (for analysis, see description below).

\section{Analyses}

\section{Growth rate}

The growth rate was calculated from the linear regression of the natural logarithm of cell density versus time (Eq. 2)

$$
\mu=\frac{\ln \left(\frac{X_{2}}{X_{1}}\right)}{t_{2}-t_{1}}
$$

where $\mu$ is the growth rate $\left(\right.$ day $\left.^{-1}\right)$, and $X_{2}$ and $X_{1}$ are the cell densities (cells $\left.\mathrm{mL}^{-1}\right)$ at time $2\left(t_{2}\right.$, day) and time $1\left(t_{1}\right.$, day) respectively.

\section{Biomass based on dry weight}

Determination of cell dry weight was done gravimetrically. About $30 \mathrm{~mL}$ of the sample was harvested by filtering over pre-dried and pre-weighed $\mathrm{GF} / \mathrm{C}$ filters. The filters were washed with $0.5 \mathrm{M} \mathrm{NH}_{3} \mathrm{HCO}_{3}$ according to $\mathrm{Zhu}$ and Lee (1997). Then, the filter was dried at $95{ }^{\circ} \mathrm{C}$ until a constant weight was reached.

\section{Carbohydrate and sEPS determination}

To analyze the intracellular carbohydrate content of P. tricornutum, $1 \mathrm{~mL}$ of the sample was centrifuged at 13,000 rpm for $5 \mathrm{~min}$. The supernatant was kept for sEPS determination. The pellet was washed twice by using cold Milli-Q water to remove remaining supernatant. The collected pellet was stored at $-20{ }^{\circ} \mathrm{C}$ until later analysis. Carbohydrate extraction was carried out by using $1 \mathrm{~mL}$ double distilled water (Milli-Q) at $80{ }^{\circ} \mathrm{C}$ for $1 \mathrm{~h}$ (Van Oijen et al. 2005). The sample was then centrifuged at $5000 \mathrm{rpm}$ for $5 \mathrm{~min}$ at $22^{\circ} \mathrm{C}$. The supernatant was collected to analyze total carbohydrates, using the total carbohydrate assay kit (Sigma, MAK104-1KT) at $490 \mathrm{~nm}$ on a Multilabel counter (Victor 1420, PerkinElmer) according to the Dubois method (Dubois et al. 1956). DGlucose was used as a standard curve.
The determination of sEPS was done by colorimetry as explained by Ramus (1977) and Guzmán-Murillo et al. (2007) with slight modifications. Briefly, $1 \mathrm{~mL}$ of cell-free culture supernatant was gently mixed with $4 \mathrm{~mL} 0.5 \mathrm{M}$ acetic acid and $500 \mu \mathrm{L}$ Alcian Blue $8 \mathrm{GX}\left(1 \mathrm{mg} \mathrm{mL}^{-1}\right.$ in acetic acid $0.5 \mathrm{M}, \mathrm{pH} 2.5$ ), vortexed at $3000 \mathrm{rpm}$ for $20 \mathrm{~s}$, and then incubated overnight at room temperature $\left(22^{\circ} \mathrm{C}\right)$. The samples were centrifuged at $3000 \times \mathrm{g}$ for $30 \mathrm{~min}$ at $22^{\circ} \mathrm{C}$. The sample was read at $610 \mathrm{~nm}$ on a Hach DR 3900, which did not interfere with the maximum peak of wastewater absorption at 320 $330 \mathrm{~nm}$. The difference in absorbance between the blank medium (30\% v/v POME or Milli-Q water) and the samples was taken as proportional polyanion concentration. Dextran sulfate was used as a standard curve.

The volumetric carbohydrate productivity was calculated based on Eq. 3 .

$P_{\mathrm{c}}=\frac{\left(X_{\mathrm{t}}-X_{0}\right) \cdot C_{\mathrm{c}}}{t}$

where $P_{\mathrm{c}}$ is the carbohydrate productivity ( $\mathrm{mg} \mathrm{L}^{-1}$ day $\left.^{-1}\right), X_{\mathrm{t}}$ is the final biomass concentration $\left(\mathrm{mg} \mathrm{L}^{-1}\right), X_{0}$ is the initial biomass concentration $\left(\mathrm{mg} \mathrm{L}^{-1}\right), C_{\mathrm{c}}$ is the carbohydrate content per total biomass dry weight $(w / w)$, and $t$ is the total duration of the cultivation (days).

\section{Nutrient analysis}

For nutrient analysis, about $5-10 \mathrm{~mL}$ of the sample were filtered using GF/F glassfiber filter (Whatman), after which the filtrate was used for dissolved nutrient analyses as described below. Total phosphorus and orthophosphate were analyzed using the assay kit LCK349 $\left(0.05-1.50 \mathrm{mg} \mathrm{L}^{-1}\right.$ orthophosphate, $0.15-4.50 \mathrm{mg} \mathrm{L}^{-1}$ TDP, provided by Hach, The Netherlands). Samples were diluted using Milli-Q water if necessary. For TDP analysis, $2 \mathrm{~mL}$ of the sample was carefully pipetted to the tube containing reagent LCK394 and hydrolyzed to a temperature block (Hach LT 200) at $100{ }^{\circ} \mathrm{C}$ for $60 \mathrm{~min}$. After cooling down to room temperature, the tube was shaken vigorously and $0.2 \mathrm{~mL}$ of reagent was added. The orthophosphate determination procedure was identical to TDP analysis except for the hydrolysis step. For total dissolved nitrogen analysis, samples were diluted with Milli-Q water if necessary due to the range of TDN provided by the assay kit (1-16 mg L ${ }^{-1}$ ) from LCK138 (Hach, The Netherlands). Briefly, $1.3 \mathrm{~mL}$ of the sample and reagents was added to a reaction tube and hydrolyzed at $120{ }^{\circ} \mathrm{C}$ for $30 \mathrm{~min}$ in the heater block. After cooling down, the kit reagent was added to the tube and shaken. Then, $0.5 \mathrm{~mL}$ of the sample was pipetted in a tube containing kit reagents (LCK138). For nitrate analysis, LCK339 (Hach) was used $\left(0.23-13.5 \mathrm{mg} \mathrm{L}^{-1}\right.$ $\mathrm{NO}_{3}-\mathrm{N}$ ) and the sample was diluted with Milli-Q if necessary. About $1 \mathrm{~mL}$ of the sample was pipetted to the tube containing 
Table 1 Growth rate of P. tricornutum cultivated on $\mathrm{F} / 2$ and on the mixture of seawater (SW) and filtered POME concentrations at $25^{\circ} \mathrm{C}$ and $300 \mu \mathrm{mol}$ photons $\mathrm{m}^{-2} \mathrm{~s}^{-1}$ (measured inside the culture). Average values of duplicate cultures are shown. SD is shown after \pm symbol. Values that do not share a common lowercase letter in the same column are significantly different $(P<0.05)$

\begin{tabular}{lcclc}
\hline Media & $\mathrm{NO}_{3}{ }^{-}-\mathrm{N}(\mu \mathrm{M})$ & $\mathrm{PO}_{4}-\mathrm{P}(\mu \mathrm{M})$ & $\mathrm{N} / \mathrm{P}_{\text {molar ratio }}{ }^{\mathrm{a}}$ & ${\text { Growth rate }\left(\text { day }^{-1}\right)}^{-1}$ \\
\hline f/2 & 880.00 & 36.90 & $24: 1$ & $1.10 \pm 0.04 \mathrm{a}$ \\
$5 \%$ POME +95\% SW & 36.79 & 2.89 & $13: 1$ & $0.30 \pm 0.06 \mathrm{~b}$ \\
$10 \%$ POME +90\% SW & 73.57 & 5.78 & $13: 1$ & $0.48 \pm 0.02 \mathrm{bc}$ \\
$30 \%$ POME +70\% SW & 220.71 & 17.33 & $13: 1$ & $0.66 \pm 0.12 \mathrm{c}$ \\
$50 \%$ POME +50\% SW & 367.86 & 28.88 & $13: 1$ & $0.63 \pm 0.05 \mathrm{c}$ \\
$70 \%$ POME +30\% SW & 515.00 & 40.44 & $13: 1$ & $0.61 \pm 0.01 \mathrm{c}$ \\
$100 \%$ POME & 735.71 & 57.77 & $13: 1$ & $0.61 \pm 0.01 \mathrm{c}$ \\
\hline
\end{tabular}

${ }^{a}$ The molar ratio is calculated from dissolved inorganic nitrogen as nitrate and dissolved phosphorus as phosphate in the media reagents (LCK339) after which $0.2 \mathrm{~mL}$ of kit reagent was added. After $15 \mathrm{~min}$, the sample was measured using spectrophotometry. Measurements were done using a Hach Lange 3900 DR spectrophotometer following the programs listed in the machine.

The efficiency of nutrient removal was calculated based on Eq. 4.

$E=\frac{n_{0}-n_{\mathrm{t}}}{n_{0}} \times 100$

where $E$ is the nutrient removal efficiency (\%), $n_{0}$ is the nutrient concentration $\left(\mathrm{mg} \mathrm{L}^{-1}\right)$ of the sample at the beginning of cultivation, and $n_{\mathrm{t}}$ is the nutrient concentration $\left(\mathrm{mg} \mathrm{L}^{-1}\right)$ of the sample at the end of cultivation.

\section{Statistical analysis}

Minitab ver. 18. (Demo version) was used for statistical analysis, GFFD and BBD design, and the evaluation. Differences between treatments were analyzed with one-way or two-way analysis of variance (ANOVA) with $P$ value of 0.05 . Post hoc tests (Tukey HSD) were performed for pair-wise comparisons. The experimental results were obtained based on at least two replicates as expressed in the standard deviations ( \pm SD).

\section{Results}

\section{Effect of POME fraction on the growth rate of $P$. tricornutum}

The highest growth rate $\left(1.10\right.$ day $\left.^{-1}\right)$ was recorded for P. tricornutum growing on $\mathrm{f} / 2$ medium, i.e., artificial medium without POME. All POME fractions showed substantially lower growth rates, ranging between 0.30 and 0.66 day $^{-1}$ (Table 1, Fig. 1). Maximum growth was observed at $30 \%$ POME: Above this fraction, growth rates decreased slightly. Therefore, $30 \% v / v$ of POME was used for all subsequent experiments.

\section{Effects of nutrient enrichment on growth rate, total biomass, carbohydrate productivity, and sEPS}

The highest temperature $\left(25^{\circ} \mathrm{C}\right)$ resulted in overall higher growth rates as compared with the $20{ }^{\circ} \mathrm{C}$ cultures $(P<0.05)$ (Table 2). At both temperatures, the growth rates after nutrient enrichment (both nitrogen and phosphorus) on 30\% POME were not significantly different compared to $\mathrm{f} / 2$ medium. The lowest growth rate was found in the control cultures based on $30 \%$ POME without nutrient addition (C) for both temperatures (Table 2$)(P<0.05)$. At $25^{\circ} \mathrm{C}$, POME with urea addition
Fig. 1 Growth profile of P. tricornutum cultivated at $25^{\circ} \mathrm{C}$ and $300 \mu \mathrm{mol}$ photons $\mathrm{m}^{-2} \mathrm{~s}^{-1}$ under different POME concentration

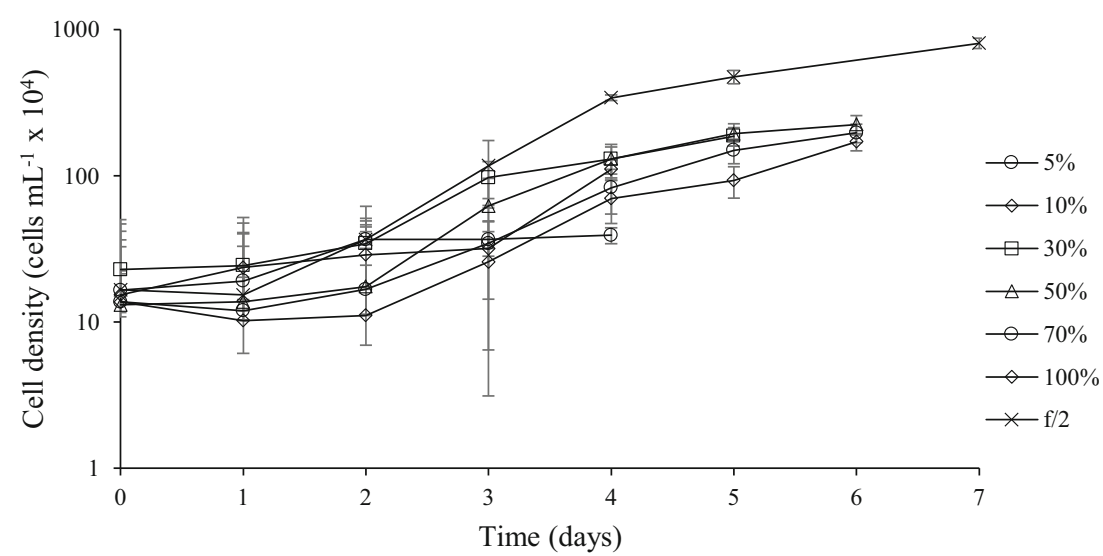




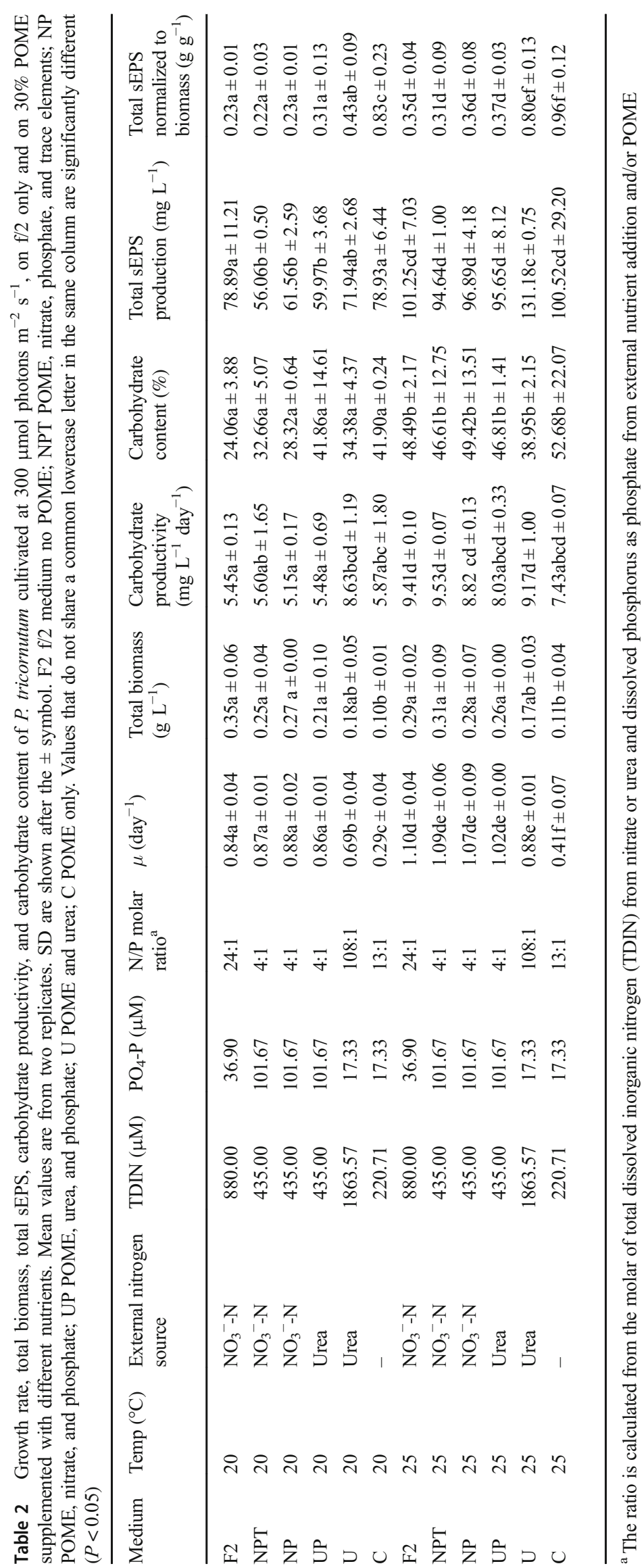


Fig. 2 Pareto chart showing the effects of parameters on the growth rate of $P$. tricornutum. The vertical line indicates the significance of the effects at $95 \%$ confidence level. A is temperature $\left({ }^{\circ} \mathrm{C}\right)$, B is salinity $(\%)$, and $\mathrm{C}$ is urea addition $\left(\mathrm{mg} \mathrm{L}^{-1}\right)$

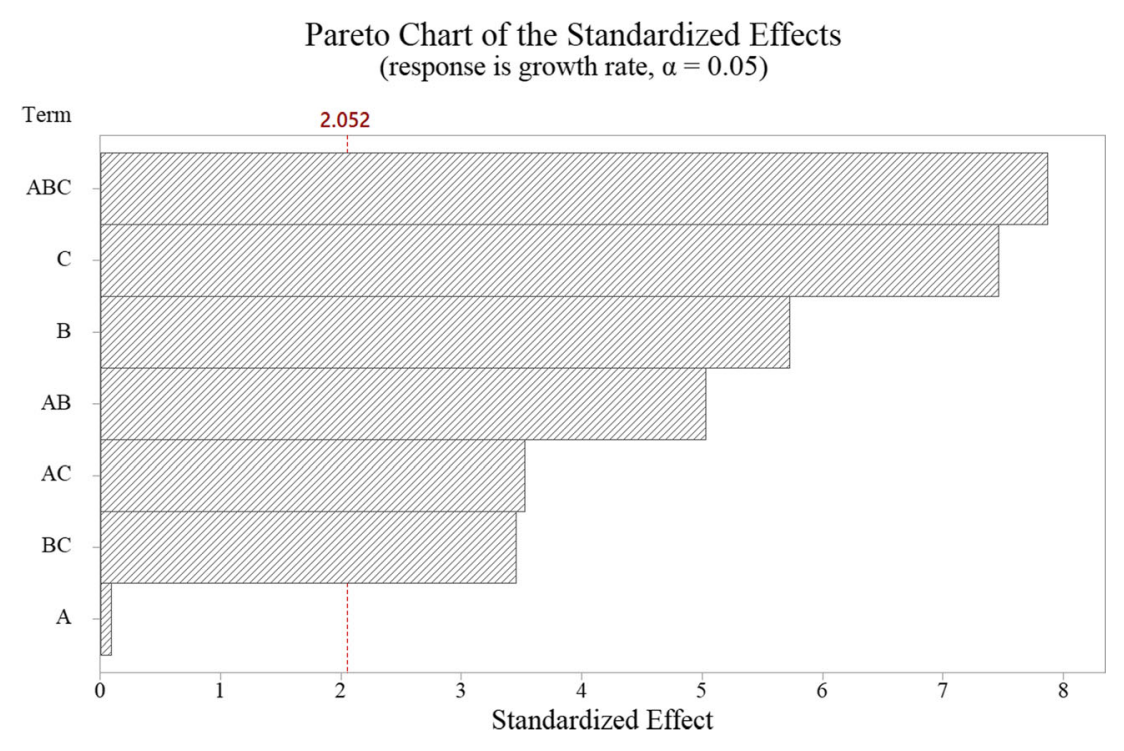

(U) alone (no phosphate addition) resulted in a growth rate averaging $0.88 \pm 0.04$ day $^{-1}$, which was significantly higher compared to $\mathrm{C}\left(0.41 \pm 0.07\right.$ day $\left.^{-1}\right)$. Furthermore, the growth rate at $25{ }^{\circ} \mathrm{C}$ was not significantly different between urea addition alone and nitrate/urea plus phosphate addition (NPT, NP, UP) $(P>0.05)$. However, at $20^{\circ} \mathrm{C}$, the growth rate after urea addition alone was significantly different compared to $\mathrm{f} / 2$, NPT, NP, and UP medium $(P<0.05)$. Based on this case, the addition of phosphorus alone could also influence growth rate at low temperature. In our research, the addition of $1 \mathrm{mg} \mathrm{L}^{-1}$ phosphate alone to POME resulted at $20{ }^{\circ} \mathrm{C}$ in a growth rate as high as the urea addition alone (data not shown).

With respect to total dry biomass production, the addition of nitrogen and phosphorus resulted in significantly different values compared to the POME control $\mathrm{C}$ at both temperatures $(P>0.05)$ (Table 2). Furthermore, the total biomass production after the addition of urea alone (U) was not significantly different compared to NPT, NP, and UP at both temperatures $(P>0.05)$. Also, no significant difference was found between both temperatures (Table 2) $(P>0.05)$.

Temperature significantly influenced carbohydrate content and total sEPS production $(P<0.05)$, while nutrient enrichment on $30 \%$ POME did not significantly influence total sEPS production at both temperatures (Table 2). Total sEPS normalized to biomass was found to be significantly higher with the addition of urea-only (U) compared to combined nutrient additions (NPT, NP, UP) at $25^{\circ} \mathrm{C}$. Furthermore, the addition of urea-only (U) resulted in no significantly different carbohydrate productivity compared to the other nutrient additions (NPT, NP, UP) at the high temperature $(P<0.05)$, although a trend was observed of elevated sEPS levels for the control and urea-only additions.

Since the urea-only conditions (U) showed positive results (growth, biomass, and sEPS higher than other nutrient additions) as compared with the $30 \%$ POME alone cultures, this addition was chosen for the last experimental series. In this way, phosphate addition was avoided.

\section{Optimization of total biomass and total sEPS as a function of salinity, temperature, and urea addition}

Based on the FFD statistical analysis, all interactive variables influenced the growth rate of $P$. tricornutum $(P<0.05)$ (Fig. 2). Increased salinity or urea concentration enhanced the growth rate, and the interactive effect of temperatureurea and temperature-salinity also enhanced the growth rate (Fig. 3). Based on the Pareto chart (Fig. 2), the interactive effect of temperature, salinity, and urea was the most influencing factor with respect to the growth rate, followed by urea addition and salinity. Therefore, temperature, urea, and salinity were chosen for the optimization of the total biomass and total sEPS based on BBM RSM (Table 3).

BBD showed that higher temperatures increased total sEPS $(P<0.05)$, while the addition of urea alone had no effect on total sEPS $(P>0.05)$ (Table 4, Fig. 4, S1). The optimal salinity was recorded at $2.0-2.5 \%(w / v)(P<0.05)$. The interactive effect of temperature-salinity and the interactive effect of temperature-urea influenced the total sEPS $(P<0.05)$ (Table 4, Fig. 4, S1).

As for total biomass, urea levels exceeding 40-80 $\mathrm{mg} \mathrm{L}^{-1}$, temperatures above $22-23{ }^{\circ} \mathrm{C}$, and a salinity exceeding 2.0 $3.5 \%(w / v)$ lowered total biomass $(P<0.05)$ (Fig. 5). Furthermore, the interactive effect between variables did not significantly influence biomass $(P>0.05)$.

\section{Nutrient removal efficiency}

TDP and TDN removal efficiency were highly dependent on the nutrient enrichment used (Fig. 6). The highest TDP removal 
Fig. 3 Response surface plot (3D) of growth rate as a function of temperature, salinity, and urea addition at hold value a)

$50 \mathrm{mg} \mathrm{L}^{-1}$ urea addition, b) $3.5 \%$ $(w / v)$ salinity, and c) temperature $22.5{ }^{\circ} \mathrm{C}$

b)

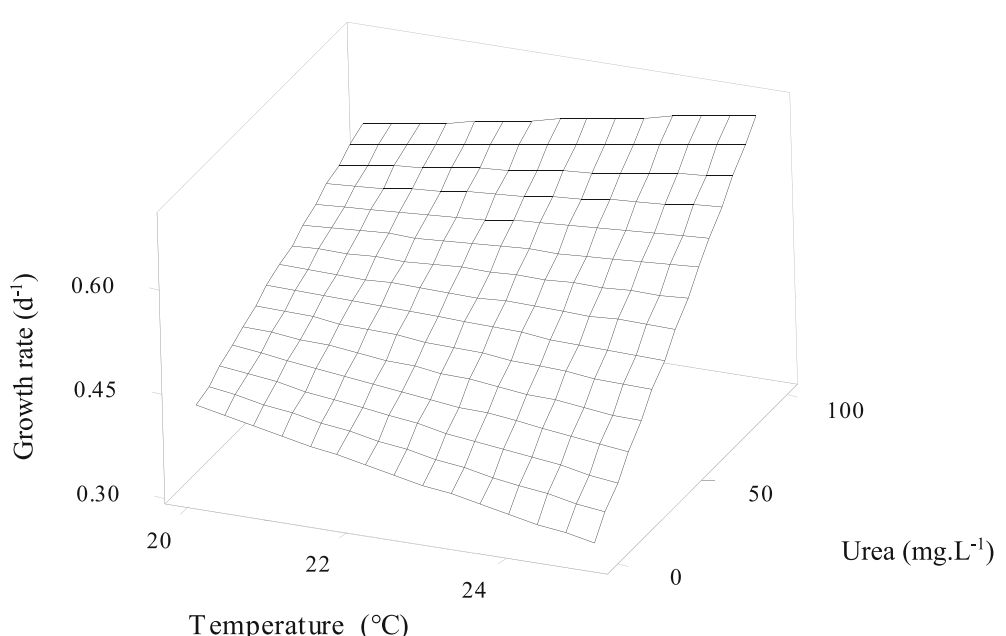

c)

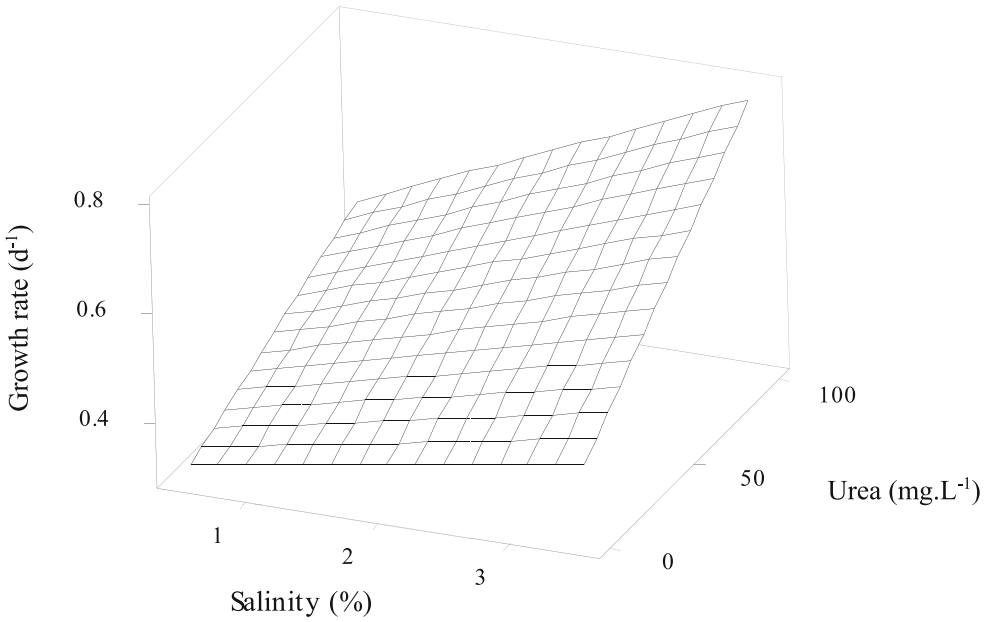

efficiency $(88.2 \pm 2.3 \%)$ was recorded for POME supplemented with urea $(\mathrm{U})$ alone (no phosphate addition). This value was

a)

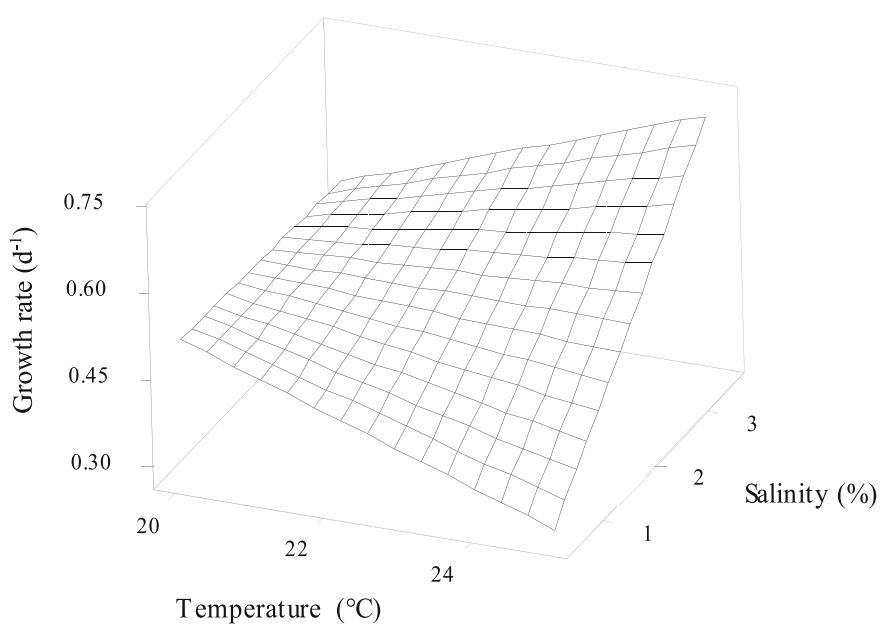

Temperature $\left({ }^{\circ} \mathrm{C}\right)$

Temperature $\left({ }^{\circ} \mathrm{C}\right)$

significantly different from the control C (POME without nutrient $68.8 \pm 3.07 \%$ ) and from the $\mathrm{P}$ (phosphate addition) (54.3 
Table 3 Design of the experiment of BBD with the results. Mean \pm $\mathrm{SD}$ values of the experimental results are from two replicates

\begin{tabular}{|c|c|c|c|c|c|c|}
\hline \multirow{2}{*}{$\begin{array}{l}\text { Temperature } \\
\left({ }^{\circ} \mathrm{C}\right)\end{array}$} & \multirow{2}{*}{$\begin{array}{l}\text { Salinity } \\
(\%)\end{array}$} & \multirow{2}{*}{$\begin{array}{l}\text { Urea addition } \\
\left(\mathrm{mg} \mathrm{L}^{-1}\right)\end{array}$} & \multicolumn{2}{|c|}{ Total biomass $\left(\mathrm{g} \mathrm{L}^{-1}\right)$} & \multicolumn{2}{|c|}{ Total sEPS $\left(\mathrm{mg} \mathrm{L}^{-1}\right)$} \\
\hline & & & Experimental & Predicted & Experimental & Predicted \\
\hline 20 & 0.5 & 50 & $0.06 \pm 0.00$ & 0.07 & $43.48 \pm 1.14$ & 48.18 \\
\hline 20 & 3.5 & 50 & $0.18 \pm 0.05$ & 0.18 & $71.94 \pm 2.68$ & 62.44 \\
\hline 20 & 2.0 & 0 & $0.08 \pm 0.01$ & 0.11 & $96.88 \pm 8.92$ & 103.87 \\
\hline 20 & 2.0 & 100 & $0.13 \pm 0.00$ & 0.13 & $87.17 \pm 0.69$ & 84.98 \\
\hline 22.5 & 0.5 & 0 & $0.08 \pm 0.01$ & 0.02 & $41.18 \pm 1.26$ & 30.68 \\
\hline 22.5 & 3.5 & 0 & $0.12 \pm 0.00$ & 0.14 & $87.33 \pm 1.17$ & 85.44 \\
\hline 22.5 & 0.5 & 100 & $0.11 \pm 0.01$ & 0.07 & $50.41 \pm 2.95$ & 46.40 \\
\hline 22.5 & 3.5 & 100 & $0.19 \pm 0.02$ & 0.17 & $65.44 \pm 0.08$ & 78.38 \\
\hline 22.5 & 2.0 & 50 & $0.24 \pm 0.11$ & 0.27 & $99.31 \pm 3.43$ & 101.65 \\
\hline 25 & 0.5 & 50 & $0.02 \pm 0.00$ & 0.02 & $33.74 \pm 1.68$ & 46.83 \\
\hline 25 & 3.5 & 50 & $0.17 \pm 0.03$ & 0.14 & $131.71 \pm 0.75$ & 119.31 \\
\hline 25 & 2.0 & 0 & $0.05 \pm 0.02$ & 0.05 & $94.45 \pm 26.77$ & 108.41 \\
\hline 25 & 2.0 & 100 & $0.12 \pm 0.01$ & 0.11 & $141.06 \pm 0.69$ & 135.97 \\
\hline
\end{tabular}

$\pm 5.1 \%)(P<0.05)$. For TDN removal efficiency, the addition of nutrients was nowhere significantly different compared to the control $(P>0.05)$. The highest TDN removal was found for POME enriched with urea $(45.2 \pm 3.1 \%)$, followed by the control $(18.4 \pm 12.2 \%)$, and $\mathrm{P}$ addition $(13.7 \pm 11.4 \%)$.

\section{Discussion}

The present study shows that optimal growth of $P$. tricornutum is achieved when growing on 30\% POME supplemented with urea. Without nutrient addition, the observed higher growth rate at 30\% POME $(v / v)$ as compared with 5 and $10 \%$ POME $(v / v)$ could be due to the relatively higher nutrient concentrations in the 30\% POME cultures (Table 1). As reported previously, POME contains high levels of micro nutrients such as iron, zinc, potassium, and magnesium, which could boost algal growth (Habib et al. 2003). Furthermore, POME may also contain acetic acid which could be utilized by $P$. tricornutum by applying mixotrophic growth (Villanova et al. 2017; Nur and Buma 2018).

In contrast, at the highest POME fractions $(>30 \% v / v)$, the slightly lower growth rates could not be explained by lower light penetration due to high turbidity in POME, as irradiance was set to saturating levels in all cultures $(300 \mu \mathrm{mol}$ photons $\mathrm{m}^{-2} \mathrm{~s}^{-1}$ ) (Nur et al. 2019). Instead, the presence of potentially toxic phenolic compounds could provide a valid explanation, since these are still contained in digested POME (Chantho et al. 2016). The total concentration of phenolic compounds in POME can reach up to $303 \mathrm{mg} \mathrm{L}^{-1}$ as demonstrated before (Neoh et al. 2013), yet unfortunately these compounds were not measured during our experiments. Marine microalgae such as Dunaliella salina and P. tricornutum were described to be more sensitive to phenolic compounds from digested POME than freshwater algae such as Chlorella vulgaris (Nur et al. 2016; Duan et al. 2017). Overall, a 30\% POME fraction was found to be most suitable to be used as growth medium for $P$. tricornutum for all subsequent experiments in this study. However, the optimal fraction is determined by the quality and the nutritional content of POME (COD, BOD, nitrogen, phosphorus, lignin) which may vary depending on factories and seasonal crops that could lead to deviations in these substances of around $\pm 20-50 \%$ (Poh et al. 2010).

Nutrient additions were found to significantly affect growth and final biomass of $P$. tricornutum growing on POME. P. tricornutum could grow well on $30 \%$ POME $(0.66 \pm$ 0.12 day $^{-1}$ ) without adding external nutrients, likely due to the favorable N/P ratio being close to Redfield (13:1) as found in a previous study (Nur et al. 2016; Hadiyanto et al. 2017). However, this growth rate was significantly lower than the artificial $\mathrm{f} / 2$ medium, which might be due to nutrient speciation

Table 4 Estimated regression uncoded coefficient of Box-Behnken design RSM for total sEPS production $\left(\mathrm{mg} \mathrm{L}^{-1}\right)$

\begin{tabular}{lccl}
\hline Variables & Coefficient & $P$ value & Remarks \\
\hline Constant & 777 & $<0.01$ & Significant \\
Temp $\left({ }^{\circ} \mathrm{C}\right)$ & -63.10 & $<0.01$ & Significant \\
Salinity $(\%)$ & 2.5 & $<0.01$ & Significant \\
Urea $\left(\mathrm{mg} \mathrm{L}^{-1}\right)$ & -1.85 & 0.534 & \\
Temp $\left({ }^{\circ} \mathrm{C}\right)$. Temp $\left({ }^{\circ} \mathrm{C}\right)$ & 1.25 & 0.228 & \\
Salinity $(\%)$. Salinity $(\%)$ & -17.90 & $<0.01$ & Significant \\
Urea $\left(\mathrm{mg} \mathrm{L} \mathrm{L}^{-1}\right)$. Urea $\left(\mathrm{mg} \mathrm{L}^{-1}\right)$ & -0.00 & 0.856 & \\
Temp $\left({ }^{\circ} \mathrm{C}\right)$. Salinity $(\%)$ & 3.88 & $<0.05$ & Significant \\
Temp $\left({ }^{\circ} \mathrm{C}\right)$. Urea $\left(\mathrm{mg} \mathrm{L}^{-1}\right)$ & 0.09 & $<0.05$ & Significant \\
Salinity $(\%)$. Urea $\left(\mathrm{mg} \mathrm{L}^{-1}\right)$ & -0.07 & 0.242 & \\
\hline
\end{tabular}


Fig. 4 Response surface plots (3D) showing the effects of temperature $\left({ }^{\circ} \mathrm{C}\right)$, urea $\left(\mathrm{mg} \mathrm{L}^{-1}\right)$, and salinity $(\%)$ on total sEPS generated by $P$. tricornutum at hold value $22.5^{\circ} \mathrm{C}$ (a) $50 \mathrm{mg} \mathrm{L}^{-1}$ (b), and $2.0 \%$ (c) a)
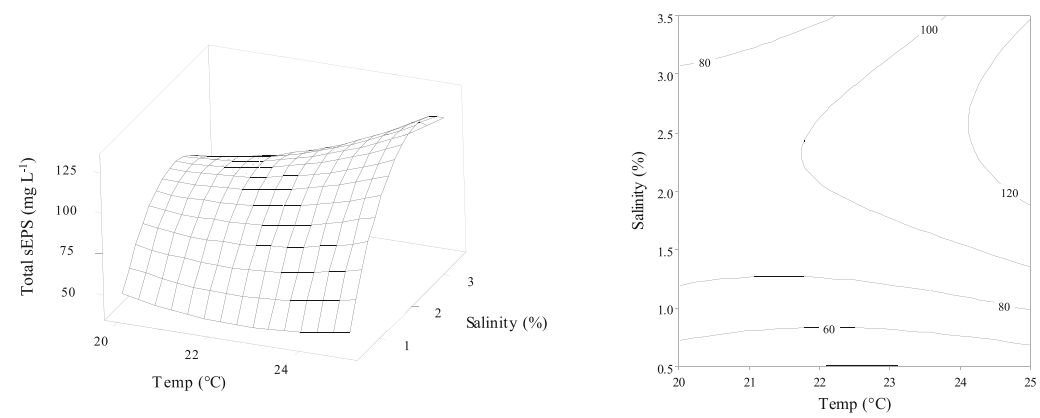

b)
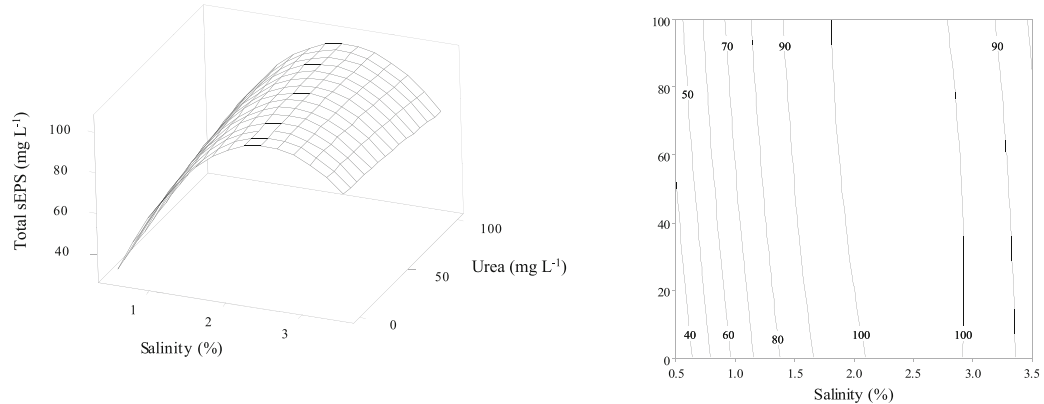

c)

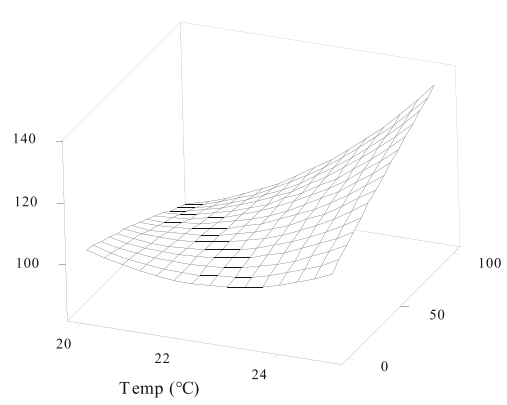

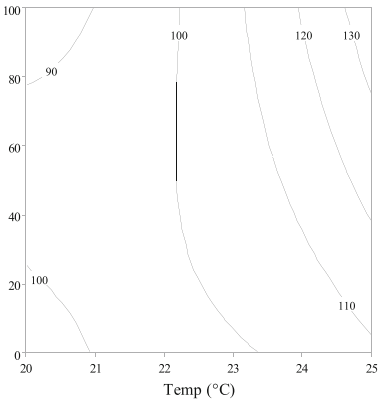

issues in the treated POME which contains relatively high organic nitrogen (Onyla et al. 2001). As a result, the addition of nutrients, in particular nitrate/urea and phosphate, significantly enhanced the growth rate at $b$ jjoth temperatures, reaching close to $\mathrm{f} / 2$ levels (Table 2). The addition of nitrogen - in this case urea-alone (U) promoted growth and total biomass to levels similar to those of nitrogen plus phosphate (NPT, NP, UP) at high temperature (Table 2). This implies that the phosphorus availability in POME does not limit the growth of $P$. tricornutum. At the same time, the addition of urea alone was found to guarantee almost complete phosphorus removal (Fig. 6). A similar result was reported earlier; at high temperatures, phosphorus exhaustion did not decrease growth rate, compared to low temperatures where phosphorus limitation inhibits growth, probably due to the fact that cells require a higher amount of nutrients with decreasing temperature (Rhee and Gotham 1981; Delgadillo-Mirquez et al. 2016).

As shown in the present study, urea can be an excellent nitrogen source for $P$. tricornutum, boosting growth rate, biomass, and phosphate removal when cultivated on POME. Therefore, compared to phosphorus addition, urea addition is more sustainable since the media containing phosphorus released to rivers could enhance eutrophication of water bodies (Poh et al. 2010). Also, the phosphorus source is more expensive than the nitrogen source which was added from cheap fertilizer (urea). However, the addition of urea may not be the best option to remove phosphorus in the large scale since urea will be left over in the medium after harvesting of the algae, when not carefully supplemented. To solve this, the media containing any excess urea could be reused as growth medium for second-stage algal growth, or recycled as palm tree fertilizer, while the sEPS produced in the filtrate could also serve as soil fertilizer (Painter 1993). Besides this, the optimum condition for urea needs to be further explored since high urea concentrations might result in lower growth rate, possibly due to urea toxicity (Collos and Harrison 2014).

Salinity and the interaction between temperature and salinity or urea significantly influenced the growth rate (Table 3). 
This outcome is of interest when $P$. tricornutum is considered for large-scale production systems. At $0.5 \%$ salinity, $P$. tricornutum showed a lower growth rate compared to 2.0 and $3.5 \%(w / v)$ Furthermore, the addition of urea did not promote growth, when salinity was low and temperature was high, possibly due to low salinity stress in P. tricornutum. Liang et al. (2014) reported that optimum growth and photosynthetic efficiency for $P$. tricornutum were recorded at 2.0$4.0 \%(w / v)$ salinity. This condition was also supported by our finding that the optimum condition for total biomass production was found at $2.0-3.0 \%(w / v)$ salinity, $40-80 \mathrm{mg} \mathrm{L}^{-1}$ urea addition, at $22-23{ }^{\circ} \mathrm{C}$ (Fig. 5).

Total sEPS production and sEPS content were found to be influenced by temperature (Table 2, Fig. 4). When temperature was relatively low, total sEPS was significantly reduced. An explanation for this could be that $P$. tricornutum accumulates sEPS when the culture is in a stressed condition to protect cells from damage (Delattre et al. 2016). Previous studies using the green alga Graesiella revealed that total EPS production increased with temperature (Mezhoud et al. 2014).

In the present study, cultivation at $25^{\circ} \mathrm{C}$ also resulted in an elevated carbohydrate content. This matches an earlier study where carbohydrate content was enhanced when $P$. tricornutum was grown at high irradiance, high temperature, around $27^{\circ} \mathrm{C}$, and low nitrogen availability, reflecting unfavorable conditions (Buono et al. 2016). In our experiments, carbohydrate content and total sEPS content in $P$. tricornutum seemed linked. Previous studies showed that the intracellular carbohydrate production of green algae was in line with the EPS production, as a response to nutrients, toxic compounds, temperature, and light intensity (El-Sheekh et al. 2012; García-Cubero et al. 2018).

Total sEPS production was also influenced by nutrient availability. Although not significant, the addition of nitrogen and phosphate to $30 \%$ POME seemed to result in lower total sEPS production compared to control (C) cultures for both temperatures (Table 2). This implies that phosphate limitation could stimulate sEPS production. The availability of nutrients with the addition of nitrogen increased total biomass but decreased total sEPS normalized to biomass (Table 2). At control $\mathrm{C}$ (POME without nutrients), low growth rates and total biomass were found, indicating that the cultures were nitrogen limited, which could result in a higher total sEPS normalized to biomass: sEPS levels were $0.83 \pm 0.23 \mathrm{~g} \mathrm{~g}^{-1}$ algal biomass at low
Fig. 5 Response surface plots (3D) showing the effects of temperature $\left({ }^{\circ} \mathrm{C}\right)$, urea $\left(\mathrm{mg} \mathrm{L}^{-1}\right)$, and salinity (\%) on total biomass $\left(\mathrm{g} \mathrm{L}^{-1}\right)$ generated by

P. tricornutum at hold value $50 \mathrm{mg} \mathrm{L}^{-1}$ (a), $22.5^{\circ} \mathrm{C}(\mathbf{b})$, and $2.0 \%(\mathbf{c})$

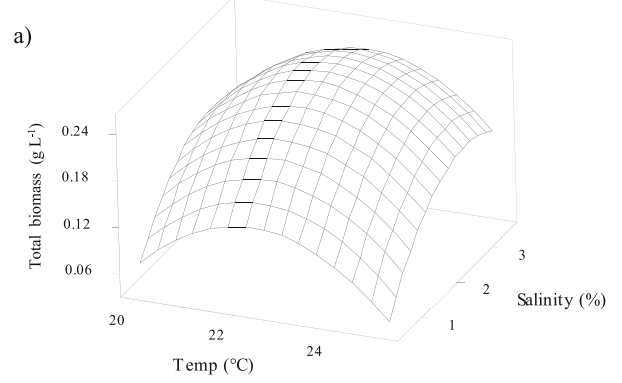

b)

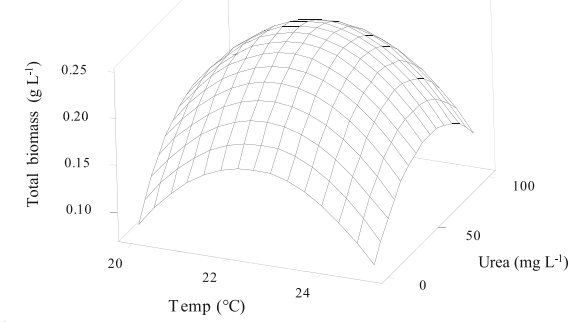

c)

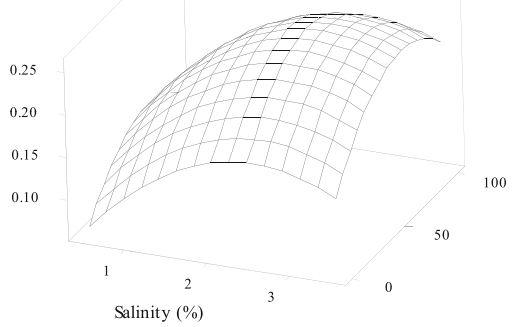

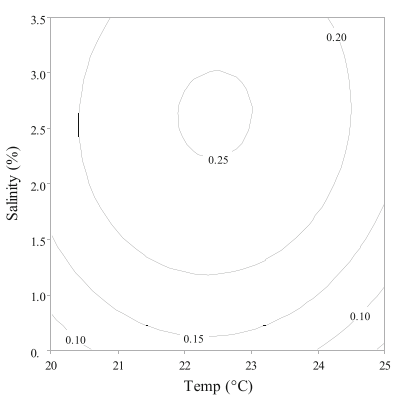
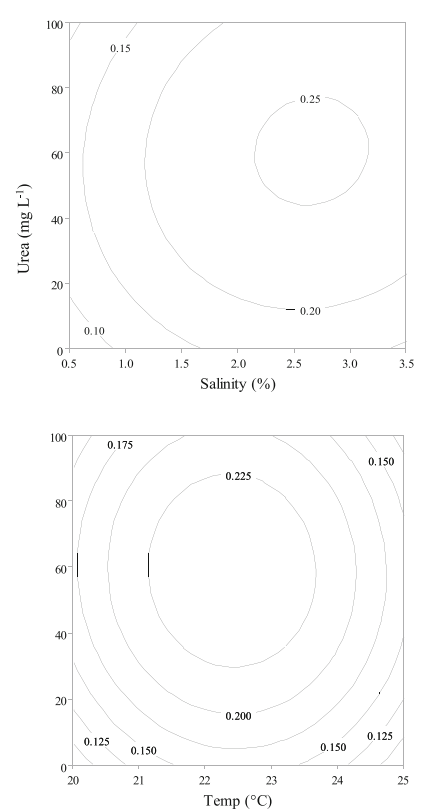
Fig. 6 Nutrient removal by P. tricornutum (at $20^{\circ} \mathrm{C}$ ) growing on $30 \%$ POME with phosphate or urea addition. $\mathrm{P}=3 \mathrm{mg} \mathrm{L}^{-1}$ phosphate addition, $\mathrm{U}=$ $50 \mathrm{mg} \mathrm{L}^{-1}$ urea addition, $\mathrm{C}=$ control POME without nutrient enrichment. Asterisk (*) indicates significantly different from other values $(P<0.05)$

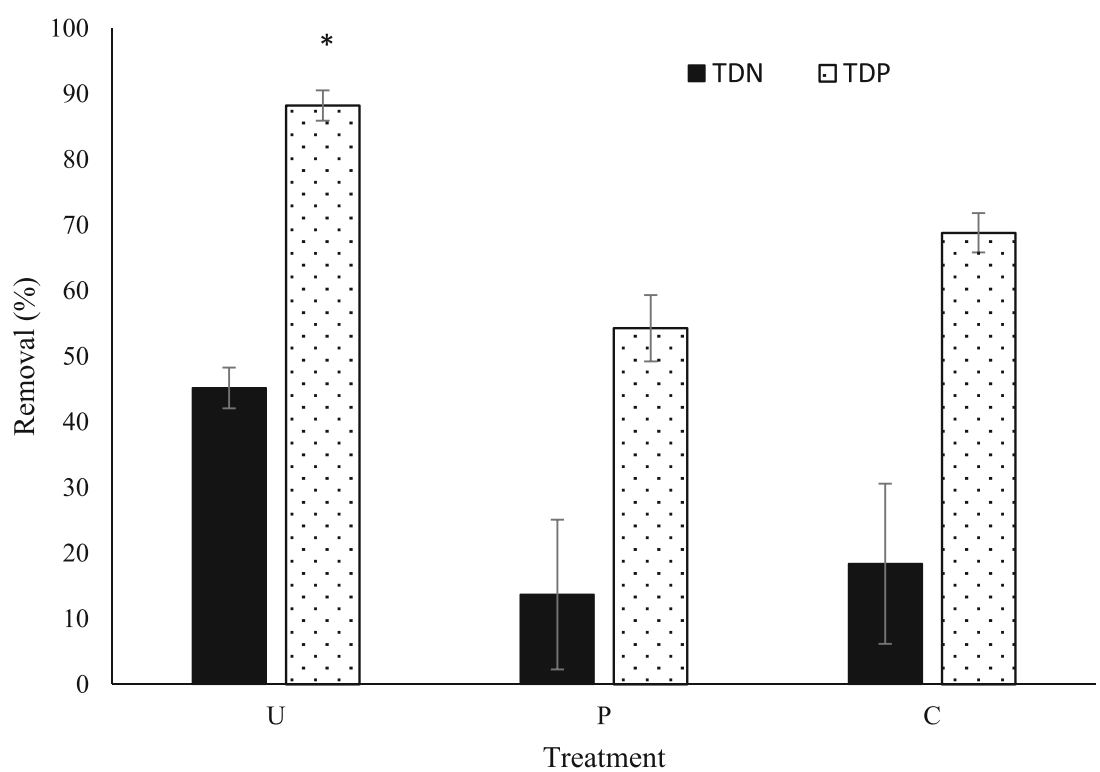

temperature and $0.96 \pm 0.12 \mathrm{~g} \mathrm{~g}^{-1}$ at high temperature. These values were 2-fold and 1.2-fold higher compared to the ureaonly cultures (Table 2). This result was supported by previous studies who found that the total exopolysaccharide (normalized to biomass) increased when Cylindrotheca closterium and Porphyridium marinum were grown in nitrogen-limited medium (Staats et al. 2000; Soanen et al. 2016).

In this work, the interactive effect of temperature and urea influenced total sEPS production. The addition of urea at high temperature promoted total sEPS production (Fig. 4). It seems that total sEPS at high temperature with the addition of urea was more dependent on the increase in total biomass production rather than total sEPS normalized to biomass. This is in accordance with earlier studies who reported that media enriched with nitrogen resulted in higher total EPS production (Lupi et al. 1994; Guerrini et al. 2000; Magaletti et al. 2004; Ekelhof and Melkonian 2017), although the total sEPS normalized to biomass was slightly lower compared to the control (POME only) (Table 2). Furthermore, the higher total sEPS normalized to biomass as found at the higher temperature (Table 2) might be explained by the interaction of temperature and urea that may become toxic at high temperatures, possibly due to the rapid hydrolysis of urea to ammonium by the cellular enzyme urease (Lomas and Glibert 1999; Glibert et al. 2008; Ni 2014). In support of this, EPS production by algae was increased when toxic compounds were added to the medium to protect cells from damage (El-Sheekh et al. 2012). In summary, in order to obtain optimal conditions for total sEPS production by $P$. tricornutum, cultivation conditions are proposed to be $25^{\circ} \mathrm{C}, 2.6 \%$ salinity, and $100 \mathrm{mg} \mathrm{L}^{-1}$ urea addition. In this way, $140 \mathrm{mg} \mathrm{L}^{-1}$ sEPS can be obtained based on the RSM approach (Fig. 4, Table 4). However, to make sEPS production more sustainable and cheap, the biomass that contained value-added products (fucoxanthin; carbohydrate) could also be used as the source of fine chemicals and bioethanol by utilizing the bio-refinery concept. In this case, the optimum biomass and sEPS could be produced by the diatom for 7 days cultivation by adding $50 \mathrm{mg} \mathrm{L}^{-1}$ urea on $30 \%$ POME. By using wastewater and adding $50 \mathrm{mg} \mathrm{L}$ of urea, the cost of fertilizer for the growth could be greatly reduced.

In conclusion, the present study has shown that P. tricornutum is a suitable candidate for effective cultivation on $30 \%$ POME while producing sEPS at the large scale, when salinity requirements are met at $2.0-3.5 \%(w / v)$. To obtain nearly complete phosphorus removal, high growth rates, and total sEPS, $25^{\circ} \mathrm{C}$ cultivation temperature needs to be accompanied by urea addition.

Funding information This project is funded by Lembaga Pengelola Dana Pendidikan (LPDP), Kementerian Keuangan, Republik Indonesia (Reference no. PRJ-72/ LPDP.3/2016).

Open Access This article is distributed under the terms of the Creative Commons Attribution 4.0 International License (http:// creativecommons.org/licenses/by/4.0/), which permits unrestricted use, distribution, and reproduction in any medium, provided you give appropriate credit to the original author(s) and the source, provide a link to the Creative Commons license, and indicate if changes were made.

\section{References}

Abdullahi AS, Underwood GJC, Gretz MR (2006) Extracellular matrix assembly in diatoms (Bacillariophyceae). V. Environmental effects on polysaccharide synthesis in the model diatom, Phaeodactylum tricornutum. J Phycol 42:363-378

Ates O (2015) Systems biology of microbial exopolysaccharides production. Front Bioeng Biotech 3:200 
Beuckels A, Smolders E, Muylaert K (2015) Nitrogen availability influences phosphorus removal in microalgae-based wastewater treatment. Water Res 77:98-106

Buono S, Colucci A, Angelini A, Langellotti AL, Massa M, Martello A, Fogliano V, Dibenedetto A (2016) Productivity and biochemical composition of Tetradesmus obliquus and Phaeodactylum tricornutum: effects of different cultivation approaches. J Appl Phycol 28:3179-3192

Chantho P, Musikavong C, Suttinun O (2016) Removal of phenolic compounds from palm oil mill effluent by thermophilic Bacillus thermoleovorans strain A2 and their effect on anaerobic digestion. Int Biodeterior Biodegrad 115:293-301

Collos Y, Harrison PJ (2014) Acclimation and toxicity of high ammonium concentrations to unicellular algae. Mar Pollut Bull 80:8-23

De Jesus Raposo MF, De Morais RMSC, De Morais AMMB (2013) Bioactivity and applications of sulphated polysaccharides from marine microalgae. Mar Drugs 11:233-252

Delattre C, Pierre G, Laroche C, Michaud P (2016) Production, extraction and characterization of microalgal and cyanobacterial exopolysaccharides. Biotechnol Adv 34:1159-1179

Delgadillo-Mirquez L, Lopes F, Taidi B, Pareau D (2016) Nitrogen and phosphate removal from wastewater with a mixed microalgae and bacteria culture. Biotechnol Rep 11:18-26

Delrue F, Álvarez-Díaz PD, Fon-Sing S, Fleury G, Sassi JF (2016) The environmental biorefinery: using microalgae to remediate wastewater, a win-win paradigm. Energies. 9:132

Díaz Bayona KC, Garcés LA (2014) Effect of different media on exopolysaccharide and biomass production by the green microalga Botryococcus braunii. J Appl Phycol 26:2087-2095

Duan W, Meng F, Lin Y, Wang G (2017) Toxicological effects of phenol on four marine microalgae. Environ Toxicol Pharmacol 52:170-176

Dubois M, Gilles KA, Hamilton JK, Rebers PA, Smith F (1956) Colorimetric method for determination of sugars and related substances. Anal Chem 28:350-356

Ekelhof A, Melkonian M (2017) Enhanced extracellular polysaccharide production and growth by microalga Netrium digitus in a porous substrate bioreactor. Algal Res 28:184-191

El-Sheekh MM, Khairy HM, El-Shenody R (2012) Algal production of extra and intra-cellular polysaccharides as an adaptive response to the toxin crude extract of Microcystis aeruginosa. Iran J Environ Health Sci Eng 9:10

Faostat (2018) http://www.fao.org/faostat/en/\#data/QD/visualize

García-Cubero R, Cabanelas ITD, Sijtsma L, Kleinegris DMM, Barbosa MJ (2018) Production of exopolysaccharide by Botryococcus braunii CCALA 778 under laboratory simulated Mediterranean climate conditions. Algal Res 29:330-336

Glibert PM, Azanza R, Burford M, Furuya K, Abal E, al-Azri A, alYamani F, Andersen P, Anderson DM, Beardall J, Berg GM, Brand L, Bronk D, Brookes J, Burkholder JAM, Cembella A, Cochlan WP, Collier JL, Collos Y, Diaz R, Doblin M, Drennen T, Dyhrman S, Fukuyo Y, Furnas M, Galloway J, Granéli E, Ha DV, Hallegraeff G, Harrison J, Harrison PJ, Heil CA, Heimann K, Howarth R, Jauzein C, Kana AA, Kana TM, Kim H, Kudela R, Legrand C, Mallin M, Mulholland M, Murray S, O’Neil J, Pitcher G, Qi Y, Rabalais N, Raine R, Seitzinger S, Salomon PS, Solomon C, Stoecker DK, Usup G, Wilson J, Yin K, Zhou M, Zhu M (2008) Ocean urea fertilization for carbon credits poses high ecological risks. Mar Pollut Bull 56:1049-1056

Guerrini F, Cangini M, Boni L, Trost P, Pistocchi R (2000) Metabolic responses of the diatom Achnanthes brevipes (Bacillariophyceae) to nutrient limitation. J Phycol 36:882-890

Guillard RRL (1975) Culture of phytoplankton for feeding marine invertebrates. In: Smith WL, Chanley MH (eds) Culture of marine invertebrate animals. Plenum Press, New York, pp 26-60

Guzmán S, Gato A, Lamela M, Freire-Garabal M, Calleja JM (2003) Anti-inflammatory and immunomodulatory activities of polysaccharide from Chlorella stigmatophora and Phaeodactylum tricornutum. Phytother Res 17:665-670

Guzmán-Murillo MA, López-Bolaños CC, Ledesma-Verdejo T, RoldanLibenson G, Cadena-Roa MA, Ascencio F (2007) Effects of fertilizer-based culture media on the production of exocellular polysaccharides and cellular superoxide dismutase by Phaeodactylum tricornutum (Bohlin). J Appl Phycol 19:33-41

Habib MAB, Yusoff FM, Phang SM, Kamarudin MS, Mohamed S (2003) Growth and nutritional values of Molina micrura fed on Chlorella vulgaris grown in digested palm oil mill effluent. Asian Fish Sci 16:107-119

Hadiyanto H, Soetrisnanto D, Silviana S, Mahdi MZ, Titisari YN (2017) Evaluation of growth and biomass productivity of marine microalga Nannochloropsis sp. cultured in palm oil mill effluent (POME). Philipp J Sci 146:355-360

Kumar AS, Mody K, Jha B (2007) Bacterial exopolysaccharides - a perception. J Basic Microbiol 47:103-107

Le Costaouëc T, Unamunzaga C, Mantecon L, Helbert W (2017) New structural insights into the cell-wall polysaccharide of the diatom Phaeodactylum tricornutum. Algal Res 26:172-179

Liang Y, Sun M, Tian C, Cao C, Li Z (2014) Effects of salinity stress on the growth and chlorophyll fluorescence of Phaeodactylum tricornutum and Chaetoceros gracilis (Bacillariophyceae). Bot Mar 57:469-476

Liew WL, Kassim MA, Muda K, Loh SK, Affam AC (2014) Conventional methods and emerging wastewater polishing technologies for palm oil mill effluent treatment: a review. J Environ Manag 149:222-235

Lomas MW, Glibert PM (1999) Interactions between $\mathrm{NH}_{4}{ }^{+}$and $\mathrm{NO}_{3}{ }^{-}$ uptake and assimilation: comparison of diatoms and dinoflagellates at several growth temperatures. Mar Biol 133:541-551

Lupi FM, Fernandes HML, Tomé MM, Sá-Correia I, Novais JM (1994) Influence of nitrogen source and photoperiod on exopolysaccharide synthesis by the microalga Botryococcus braunii UC 58. Enzym Microb Technol 16:546-550

Magaletti E, Urbani R, Sist P, Ferrari CR, Cicero AM (2004) Abundance and chemical characterization of extracellular carbohydrates released by the marine diatom Cylindrotheca fusiformis under $\mathrm{N}$ and P-limitation. Eur J Phycol 39:133-142

Mezhoud N, Zili F, Bouzidi N, Helaoui F, Ammar J, Ouada HB (2014) The effects of temperature and light intensity on growth, reproduction and EPS synthesis of a thermophilic strain related to the genus Graesiella. Bioprocess Biosyst Eng 37:2271-2280

Neoh CH, Yahya A, Adnan R, Abdul Majid Z, Ibrahim Z (2013) Optimization of decolorization of palm oil mill effluent (POME) by growing cultures of Aspergillus fumigatus using response surface methodology. Environ Sci Pollut Res 20:2912-2923

Ni WM (2014) Impact of nutrients and temperature on algal growth and relative abundance of Xixi wetland, China. Appl Mech Mater 665: 426-429

Nur MMA, Buma AGJ (2018) Opportunities and challenges of microalgal cultivation on wastewater, with special focus on palm oil mill effluent and the production of high value compounds. Waste Biomass Valor. https://doi.org/10.1007/s12649-018-0256-3

Nur MMA, Setyoningrum TM, Budiaman IGS, Kristanto D (2016) Utilization of microalgae cultivated in palm oil mill wastewater to produce lipid and carbohydrate by employing microwave-assisted irradiation. Recent Innov Chem Eng 9:107-116

Nur MMA, Setyoningrum TM, Budiaman IGS (2017) Potency of Botryococcus braunii cultivated on palm oil mill effluent wastewater as a source of biofuel. Environ Eng Res 22:417-425

Nur MMA, Muizelaar W, Boelen P, Buma AGJ (2019) Environmental and nutrient conditions influence fucoxanthin productivity of the marine diatom Phaeodactylum tricornutum grown on palm oil mill effluent. J Appl Phycol 31:111-122 
Onyla CO, Uyub AM, Akunna JC, Norulaini NA, Omar AKM (2001) Increasing the fertilizer value of palm oil mill sludge: bioaugmentation in nitrification. Water Sci Technol 44:157-162

Painter TJ (1993) Carbohydrate polymers in desert reclamation: the potential of microalgal biofertilizers. Carbohydr Polym 20:77-86

Poh PE, Yong WJ, Chong MF (2010) Palm oil mill effluent (POME) characteristic in high crop season and the applicability of high-rate anaerobic bioreactors for the treatment of POME. Ind Eng Chem Res 49:11732-11740

Ramus J (1977) Alcian blue: a quantitative aqueous assay for algal acid and sulfated polysaccharides. J Phycol 13:345-348

Rhee G-Y, Gotham IJ (1981) The effect of environmental factors on phytoplankton growth: temperature and the interactions of temperature with nutrient limitation. Limnol Oceanogr 26:635-648

Smith VH, Tilman GD, Nekola JC (1998) Eutrophication: impacts of excess nutrient inputs on freshwater, marine, and terrestrial ecosystems. Environ Pollut 100:179-196

Soanen N, Da Silva E, Gardarin C, Michaud P, Laroche C (2016) Improvement of exopolysaccharide production by Porphyridium marinum. Bioresour Technol 213:231-238

Staats N, Stal LJ, Mur LR (2000) Exopolysaccharide production by the epipelic diatom Cylindrotheca closterium: effects of nutrient conditions. J Exp Mar Biol Ecol 249:13-27
Tabassum S, Zhang Y, Zhang Z (2015) An integrated method for palm oil mill effluent (POME) treatment for achieving zero liquid discharge - a pilot study. J Clean Prod 95:148-155

Tong SL, Jaafar AB (2004) Waste to energy: methane recovery from anaerobic digestion of palm oil mill effluent. Energy Smart 4:1-8

Van de Poll WH, Visser RJW, Buma AGJ (2007) Acclimation to a dynamic irradiance regime changes excessive irradiance sensitivity of Emiliania huxleyi and Thalassiosira weissflogii. Limnol Oceanogr 52:1430-1438

Van Oijen T, Veldhuis MJW, Gorbunov MY, Nishioka J, Van Leeuwe MA, De Baar HJW (2005) Enhanced carbohydrate production by Southern Ocean phytoplankton in response to in situ iron fertilization. Mar Chem 93:33-52

Villanova V, Fortunato AE, Singh D, Bo DD, Conte M, Obata T, Jouhet J, Fernie AR, Marechal E, Falciatore A, Pagliardini J, le Monnier A, Poolman M, Curien G, Petroutsos D, Finazzi G (2017) Investigating mixotrophic metabolism in the model diatom Phaeodactylum tricornutum. Phil Trans Roy Soc B 372:20160404

Zhu CJ, Lee YK (1997) Determination of biomass dry weight of marine microalgae. J Appl Phycol 9:189-194

Publisher's note Springer Nature remains neutral with regard to jurisdictional claims in published maps and institutional affiliations. 